\title{
Cultural Scripts and the Speech Act of Opinions in Irish English: A Study amongst Irish and Polish University Students
}

\begin{abstract}
Studies in pragmatics have been limited to a handful of illocutionary acts such as requests, apologies or compliments, and opinions remain underrepresented in the existing literature. In this paper I present the results of a study of opinions in Irish English, conducted in an intercultural environment of Irish-Polish interactions. Departing from a traditional approach of speech act realisation studies, I applied the theory of cultural scripts to analyse opinions. In contrasting the Irish and Polish formulas for expressing opinions, as well as sociopragmatic attitudes towards this speech act, a difference in the cultural scripts for opinions in each culture was observable. Apart from already documented Polish frankness in opinions, the study discovered also a rational approach to presenting good arguments to support one's assertions among the participants. In relation to the Irish script for opinions, the findings are in line with previous classifications of opinions in Australian English, showing a certain level of variational uniformity amongst the English-speaking cultures in this regard.
\end{abstract}

Keywords: opinions; Irish English; cultural scripts; Polish; intercultural pragmatics

\section{Kulturni skripti in govorno dejanje izražanja mnenja v irski angleščini: Raziskava med irskimi in poljskimi študenti}

\author{
POVZETEK
}

Dosedanje raziskave na področju pragmatike so se omejevale na zgolj nekaj ilokucijskih dejanj, na primer na prošnje ali zahteve, opravičila in poklone, medtem ko so mnenja v obstoječi literaturi slabše zastopana. $\mathrm{V}$ članku so predstavljeni rezultati študije mnenj v irski angleščini, ki je bila izvedena v mednarodnem okolju irsko-poljske interakcije. Za razliko od tradicionalnejšega pristopa $\mathrm{k}$ raziskavam realizacije govornih dejanj je tu za analizo mnenj uporabljena teorija kulturnih skriptov. Skozi primerjavo irskih in poljskih formul za izražanje mnenj ter sociopragmatičnih stališč do tega govornega dejanja se pokaže razlika med kulturama pri kulturnih skriptih za mnenja. Poleg že dokumentirane poljske odkritosti v mnenjih razkriva študija tudi racionalni pristop k predstavljanju dobrih argumentov za podporo lastnih trditev nasproti drugim udeležencem. Ko gre za irski skript za mnenja, se ugotovitve ujemajo s predhodnimi klasifikacijami mnenj v avstralski angleščini in tako v tem oziru kažejo na določeno stopnjo variacijske uniformnosti med angleško govorečimi kulturami.

Ključne besede: mnenja; irska angleščina; kulturni skripti; poljščina; medkulturna pragmatika 


\section{Cultural Scripts and the Speech Act of Opinions in Irish English: A Study amongst Irish and Polish University Students ${ }^{1}$}

\section{Introduction}

The social and linguistic landscape of Ireland has changed dramatically in the last decade. Ireland saw a boom of inward migration after the 2004 European Union expansion, which attracted many workers from the new member states as a result of economic prosperity known as the Celtic Tiger. One of the largest immigrant groups that speak a language other than English has been the Polish community, which by 2011 increased to 122,585 (Central Statistics Office 2012, 7), despite the economic downturn after 2008. This cultural and linguistic contact between Irish and Polish communities also inspired the research described here.

Politeness across cultures has been the focal point of researchers in numerous studies investigating how people 'do things with words' in different speech communities. Some of the most documented aspects have been requests and apologies, which can be formulated in many ways in different cultures and languages. Problems usually occur when formulas which work perfectly in one language (such as the imperative for requests in Polish) are transferred or translated into another one in which they are not the preferred form, such as English (see Zinken and Ogierman 2013). Repetitive occurrences of linguistic transfers lead to stereotyping and miscommunication. In some cases, language may be used to actually cause offence, and impoliteness studies (namely, by authors such as Culpeper (2011)) investigate how 'rude' language functions. However, in general, misunderstandings are more often than not unintentional and cross-cultural studies help us to understand how and why they come about. Moreover, cross-cultural pragmatic research can also prescribe ways to overcome differences in the quest of building more harmonious multicultural societies. In fact, the topic of politeness has been attracting the attention of the general public too, recent cross-cultural research being reported in newspapers such as the Daily Mail (Doughty 2012).

When discussing intercultural communication, another interesting area to study would be casual conversations. In such situations, people usually tell stories and jokes, gossip or exchange opinions (see Eggins and Slade 1997). Incidentally, in reference to the Irish and Polish cultures in contact, opinions are also the type of talk where different linguistic and cultural preferences can be identified. 'Pity him who makes his opinions a certainty' says an old Irish proverb guiding us in knowing the difference between an opinion and a fact ("World Proverbs: Proverbs with Opinion" 2005-2013). But no such proverb exists in Polish. Additionally, previous research suggests that speakers of Polish often overstate, while speakers of English tend to understate their opinions (Wierzbicka 1985, 163). An important question to ask is what happens when the two cultures and languages meet, specifically in reference to the high number of Polish people living in Ireland. Furthermore, speakers of Irish English (henceforth IrE) are said to be indirect and avoid disagreement even more than those of other English-speaking nations (Kallen 2005b, 53). These differences could result in a sociocultural clash between Polish and Irish speakers exchanging opinions. Comparing how Irish and Polish speakers of English express opinions can indeed shed light on the linguistic and cultural differences between them.

This article is based on the author's PhD thesis (Gąsior 2014), University of Limerick, with minor parts reproduced verbatim. 
The cultural scripts for opinions presented here are taken from a broader investigation of opinions in IrE in contrast with Irish-Polish interactions (Gąsior 2014). In this paper I zoom in on the analysis within the cultural scripts framework, which should allow me to offer a new perspective on opinions and an opportunity to refer also to the 'bigger picture' by zooming out and discussing the characteristics of Irish politeness and opinions as a speech act in English.

\section{Literature Review}

\subsection{Prelude}

Given the importance of the concept of culture in this paper, a working definition of the term is due. Since the main theoretical framework in this paper is that of Natural Semantic Metalanguage and cultural scripts, I also adopt Wierzbicka's definition of the term (which she, in turn, introduces following Geertz 1979, 89, quoted in Wierzbicka 1997, 20-21): "The culture concept to which I adhere denotes a historically transmitted pattern of meanings embodied in symbols, a system of inherited conceptions in symbolic forms by means of which people communicate, perpetuate and develop their knowledge about and attitude towards life."

Furthermore, Wierzbicka argues that "language - and in particular, vocabulary - is the best evidence of the reality of 'culture' in the sense of a historically transmitted system of 'conceptions' and 'attitudes'" $(1997,21)$. This is an especially good object of study as both language and culture are heterogeneous and changeable. Keeping this in mind, the discussion provided in this study should be seen as only a snapshot of the cultures and languages involved, providing an insight into one particular aspect and not a definite classification of the nations discussed here.

In order to provide a sound basis for the discussion, I firstly review relevant characteristics of opinions in the Irish and Polish traditions, the research background, and offer an overview of the theory of cultural scripts. After that, I turn to the details of the empirical study carried out. Later, the presentation of research results and their accompanying examples is followed by a discussion and a conclusion.

\subsection{Opinions}

Studies in pragmatics have identified opinions as a possible point of friction between Polish and Anglo ${ }^{2}$ cultures. Opinions in Polish are expressed "fairly forcefully" and they are rather similar to statements of fact (Wierzbicka 1985, 160). Furthermore, being statements of 'truth', opinions in Polish are not typically introduced by 'I think', 'I believe' or 'in my view'. On the other hand, in English "the difference between fact and opinions is usually expressed lexically, with opinions containing either expressions of modality, or appraisal lexis" (Eggins and Slade 1997, 193-94). The preference for differentiating between opinions and facts in English to some extent reveals that there may be more deeply engrained presumptions about one's right to an opinion and preferences for expressing them. Wierzbicka $(2003,44)$ summarised this cultural Anglo value by saying that "in English, hedged opinions go hand in hand with hedged, indirect questions, suggestions or requests. People avoid making 'direct', forceful comments as they avoid asking 'direct', forceful questions or making 'direct', forceful requests."

Following Wierzbicka (2006), the term 'Anglo' is used here to denote the linguistic and cultural heritage of the inner-circle of Englishes (synonymously to the use of term 'Anglo-American'). However, some aspects of Irish English may not fall under the category 'Anglo', showing uniqueness to the Irish context and derivation not traceable to the 'Anglo' culture. 
Conversely, the confrontational style in Polish may seem overly direct or even rude to outsiders. However, as Rakowicz $(2009,9)$ concluded, "the prevailing wisdom is [...] that if we all agreed, we would have nothing to talk about. If there is disagreement, discussion is possible."

The Anglo preference for indirectness and respect for one's autonomy is reflected in a rather elaborate framework of hedges in English. Everyday conversations are full of expressions such as 'kind of', 'I think', 'well', 'perhaps', 'rather', 'I mean', 'somehow', 'I guess'. "Polish [on the other hand] tends to overstate (for emphasis) rather than understate. In Polish, opinions are expressed directly, forcefully and, one might say, dogmatically; in English, they tend to be expressed tentatively and to be clearly distinguished from statements of fact" (Wierzbicka 1985, 163). Comparing French and English, the same dichotomy has been pointed out by Mullan $(2010,59)$, who claims that "expressing opinion is highly valued among French speakers, whereas Australian English speakers may remain noncommittal for the sake of social harmony or at least do not impose their opinion on their interlocutor." A similar point was put forward by Brown and Levinson $(1987,116)$, who assigned the hedging of opinions in English to the positive politeness strategies, "so as to make one's opinion safely vague" and minimise disagreement. As the authors further explained, hedges, such as 'sort of', 'like' or 'in a way' "may be used to soften face-threatening acts of suggesting or criticizing or complaining, by blurring the speaker's intent" (Brown and Levinson 1987, 116). This may also be applied to expressing opinions.

Generally speaking, English-speaking cultures conceal their true feelings to maintain a more pleasant interaction on the surface since sharp opinions are believed to disrupt "social conviviality" (Stewart and Bennett 1991, 150). Wierzbicka $(1985,154)$ suggested this particular cultural assumption was reflected in English speech as follows:

Everyone has the right to their own feelings, their own wishes, their own opinions. If I want to show my own feelings, my own wishes, my own opinions, it is all right, but if I want to influence somebody else's actions, I must acknowledge the fact that s/he, too, may have his/ her feelings, wishes or opinions, and that these do not have to coincide with mine.

When it comes to 'agreeing to disagree' or 'compromising', Polish speakers appear to dislike the latter, that is, isć na kompromis. The word kompromis has a pejorative meaning in Polish suggesting a "moral weakness, a deplorable lack of firmness, a sell-out of values" (Wierzbicka 2003, 49). Similarly, being inflexible (nieugięty) has a positive connotation in Polish but it is negatively evaluated in English. Standing firmly by one's beliefs is a desirable attitude in Poland, while compromising is something undesired one "gives into" (Wierzbicka 1985, 164-65). On the other hand, in English, reaching a compromise can often sound like a goal, an objective that can be reached, even though it can also have some negative connotations (Kalisz 1993, 114). A book by Paul Super $(1939,75)$, an American immigrant in pre-World War II also described the Polish attitude to compromising by saying that "[the] Pole is a poor compromiser; in no aspect of life is he a more confirmed idealist than in his dislike to compromise."

In a similar account of experiences of an American in Poland, Klos Sokol talked about cultural and linguistic differences between the two nations, noticing that Americans tend to exaggerate positive aspects and minimise any negativity by hedging. Therefore, "when Americans say it was great, I know it was good. When they say it was good, I know it was okay. When they say it was okay, I know it was bad" (Klos Sokol 1997, 176). On the other hand, in Poland, these qualifiers are more moderate and the need to minimise speaking in negative terms may not be as pronounced.

Hoffman's $(1989,146)$ memories of learning English in Canada after emigrating from Poland as a teenager also point towards the issue of indirect, hedged opinions: 
I learn also that certain kinds of truth are impolite. One shouldn't criticize the person one is with, at least not directly. You shouldn't say, "You are wrong about that" - though you may say, "On the other hand, there is that to consider." You shouldn't say, "This doesn't look good on you," though you may say, "I like you better in that other outfit." I learn to tone down my sharpness, to do more careful conversational minuet.

Overall, the cultural preferences for direct expression of beliefs in Poland and a stronger preference for indirectness in the English-speaking world may be identified as a possible area of conflict. Since exchanges of opinions are often associated with disagreements and a juxtaposition of viewpoints, the way one engages in such face-threatening activities may lead to interpretations of interlocutor's strategies as being impolite in intercultural Anglo-Polish encounters. This possible threat was also an incentive to investigate opinions in this context.

\subsection{Cultural Scripts}

Traditional studies of how 'people do things with words' in different languages and cultures have been approached from the perspectives of speech acts and politeness studies, such as the seminal CCSARP study (Blum-Kulka, House, and Kasper 1989). As an alternative approach, Goddard and Wierzbicka (2004) proposed a framework which provides an objective, universal language to study languages and cultures, the Natural Semantic Metalanguage (Wierzbicka 1996). The NSM can be then used to formulate cultural scripts, which are "a powerful new technique for articulating cultural norms, values and practices in terms which are clear, precise and accessible to cultural insiders and to cultural outsiders alike" (Goddard and Wierzbicka 2004, 153).

The metalanguage of semantic primes or NSM consists of about 60 words and grammatical patterns which are thought to have their equivalents in all languages (Goddard 2008, 1). The lexical primes in the NSM include a minimal number of words in a series of categories, which together form a language sufficient to label different sociolinguistic phenomena and compare them between various languages and cultures in a systematic and objective way. In the NSM language, the substantives, for instance, include I, YOU, SOMEONE, SOMETHING and PEOPLE; mental predicates are limited to THINK, KNOW, WANT and FEEL; while various other evaluators and descriptors are based on dichotomies of GOOD-BAD, BIG-SMALL, etc. (cf. Goddard 2002, 14). The language can be then used to represent different phenomena, especially abstract ideas, using the simplest words in the form of cultural scripts. Wierzbicka $(2006,23)$ described the theory of cultural scripts as a step forward from ethnography of speaking to "ethnography of thinking." The cognitivesemantic focus of cultural scripts opens a path to study social practices, such as speaking, in order to gain a deeper understanding of a particular society's attitudes and values.

The theory of cultural scripts stems from a universalist perspective and a belief that "we need to understand people (both individuals and social groups) in their particularity, but that we can understand them best in terms of what is shared, and that one thing that is shared is a set of universal human concepts with their universal grammar" (Wierzbicka 2006, 24).

However, despite the universality outlook, cultural scripts aim to discover emic understandings of cultures. Therefore, the universality of the cultural scripts theory is represented in the language used to describe cultures, presuming a common language with lexical universals and a universal grammar. The individual explorations of cultural traits in different societies, however, are not aimed at formulating universal theories. 
The empirical focus on studying language as a reflection of culture is one of the biggest strengths of the cultural scripts theory. For instance, an examination of the semantic shift of the English word 'rather' across time can also reveal a shift in the value of hedging in the English culture. Whereas in pre-Shakespearean English 'rather' meant 'earlier', its meaning then shifted to being an 'anti-exaggeration device', reflecting a change in the need not to exaggerate in the English society (Wierzbicka 2006,31). Consequently, a cultural script which reflects this need to avoid exaggeration could be formulated as the following:

[people think like this:]

sometimes when people want to know that something is big

they say words like 'very big'

sometimes when people want to know that something is bad

they say words like 'very bad'

it is not good if a person speaks [says things] in this way

(Wierzbicka 2006, 31)

The initial research within the NSM and cultural scripts frameworks focused on analysing different cultures by their "key words," thus identifying sociocultural changes over time through chronological lexical analyses (Wierzbicka 1997). However, this approach has been criticised for trivialising national cultures (Ramson 2001) and presenting rather inconclusive results (Aitchison 1999). A methodological flaw often quoted was Wierzbicka's choice of sources for analysis, for instance, not consulting the Oxford English Dictionary in analysing English language/culture (Ramson 2001, 182). On the other hand, another decade of research into NSM and semantic primitives has evolved in the direction of more systematic tests, responding to earlier criticisms of "superficial analyses" and "hard to pin down frameworks" (Aitchison 1999, 88). Moreover, the use of corpus analysis and established approaches in lexicography can help to complement and strengthen the NSM and cultural scripts framework (such as Mullan 2010). Further application of the framework to other cultures, languages and speech acts should also be seen as an attempt to validate and test the value of this approach (cf. Murray and Button 1988).

In conclusion, the NSM and cultural scripts can be quite helpful in supplementing politeness research and speech act studies. The focus on drawing a link between language use and the underlying cultural values behind the use could be seen as also drawing a link between pragmalinguistics and sociopragmatics. However, its biggest advantage is that it allows explaining complex cultural concepts with great clarity. Thanks to this transparency, the theory of cultural scripts is a paramount element in the discussion of the results of my study.

\section{The Study}

\subsection{Participants and Data}

The data for analysis of opinions were gathered through experimental methods (open role-plays and focus groups), which allowed good control of variables and provided comparable sets of records in the two groups investigated. The interactional role-play data were gathered in two linguistic groups communicating in English; one consisting of Polish-Irish pairings and the other recording interactions of Irish-Irish dialogues. This was supplemented with focus group interviews which explored issues of sociopragmatic attitudes and awareness in expressing opinions. A mixed-method 
approach allowed for a more comprehensive study of opinions and drawing a stronger link between the linguistic role-play data and the sociopragmatic information from the focus groups. ${ }^{3}$

The sample in this study was selected using a mixture of purposeful and snowball sampling (Patton 2002, 243). The selection criteria for participation were quite general, that is, native speakers of Polish as well as IrE were sought to take part. To ensure comparability between the linguistic groups, the sample was limited to students of a university in the West of Ireland, both undergraduate and postgraduate. In total, data were gathered from 32 informants, specifically, 8 Polish and 24 Irish participants. The average age of all participants was 24; with a somewhat male-prevailing gender distribution (every 2 out of 3 participants were male).

There were six role-play scenarios which varied in terms of Power, Distance and Imposition (PDI) scores, traditionally used in speech act studies. Some participants therefore took on roles of a Boss, Friend and a Stranger to represent the situational variability in the scenarios (in the Polish-Irish role-plays, only the Irish participants took on those roles).

The research participants were instructed to start interacting immediately after reading the cue card, continuing until the conversation reached its natural end. The focus group interviews that followed the role-plays had a semi-structured design and were conducted in Polish or English, according to the linguistic group. The main issues discussed in the focus groups centred around general rules of expressing opinions (in Ireland), the emotional involvement in expressing them, and issues such as ways of disagreeing agreeably.

The corpus of interactions collected amounted to approximately 27,000 words of role-plays and 16,500 words of focus groups. The relatively small amount of data allowed for a detailed qualitative analysis of the role-plays, which can be seen as an advantage in discourse studies (O'Keefe, Clancy, and Adolphs 2011, 28). This also permitted a thorough involvement of the researcher in the qualitative analysis of the focus groups. The results presented in this paper refer mostly to the focus group data.

\subsection{Analytical Approach}

The qualitative analysis of the role-play data was influenced by two main disciplines: the tradition of cross-cultural speech act studies (Blum-Kulka, House, and Kasper 1989) and discourse analysis (Schiffrin, Tannen, and Hamilton 2001). Therefore, the units of meaning investigated in the role-plays were designed similarly to the analytical framework for other speech act studies, focusing on head acts and supportive moves, with their derivatives. The qualitative analysis of politeness strategies focused on describing strategies in categories of face-threatening, face-saving and face-enhancing moves, and was supported at times with quantitative analyses using WordSmith Tools corpus analytical software (Scott 2006). Additionally, the concept of cultural scripts (Goddard and Wierzbicka 2004) played a significant supplementary function in the analyses. While the originator (Wierzbicka 2006) of cultural scripts refers to them as a theory and a research technique, the concept was applied to the analysis of opinions as an additional analytical and explanatory perspective. Moreover, it allowed a clear cross-cultural comparison between Polish and Irish attitudes towards opinions.

The focus groups were analysed within a thematic analysis approach (Braun and Clarke 2006). A thematic analysis requires a strong interpretative involvement of the researcher, since it can entail

The transcriptions were based on the LCIE corpus (Farr, Murphy, and O'Keefe 2004), VOICE corpus conventions (2007) and Jefferson (2004). To ensure easy readability, the pronoun I and proper nouns have been capitalised and punctuation typical of literary texts has been used. Commas signal short pauses; ellipses signal pauses typical in hesitant speech; laughter is represented with the @ symbol, and the equal sign = is used to to represent latched speech. 
identifying themes expressed implicitly (Guest, MacQueen, and Namey 2012,10). After the initial identification of themes, later analysis can also include comparing code frequencies or "identifying code co-occurrence, and graphically displaying the codes within the data set" (Guest, MacQueen, and Namey 2012, 10). However, the position of the researcher and the underlining theories which guide the interpretation of themes with reference to research questions play the key part in thematic analysis. In fact, as Braun and Clarke (2006) argued, the subjectivity of the analysis carried out by the researcher is the strength of thematic analysis, not a drawback. Carrying out the data collection and transcription phases ensured the researcher's high familiarity with the content of the focus groups and, consequently, a thorough involvement in the various stages of analysis.

\section{Results and Discussion}

\subsection{Role-Play Results}

While, in English, the difference between an opinion and a fact is believed to be quite clear, in analysing the role-play data structurally it appeared that the moves labelled as either opinion or evidence cannot be easily separated. While an opinion can stand by itself and does not need to be supported by evidence, the evidence move has more significance than just supporting the opinion. Evidence, in fact, acts as not only support for the opinion, but as an implied repetition of the opinion. Thus, the illocutionary strength of saying "I think Christmas products are on sale too early" can be almost the same as saying "It's only October" or "We haven't had Halloween yet" (one of the role-play scenarios discussed opinions about the Christmas hype in Ireland). Conceptually, the first utterance would count as an opinion, and the other two as evidence (since they are facts). However, the shared common knowledge between the interlocutors allows both to interpret the presentation of facts as grounding as well as the implied opinion in one move. By saying "It's only October," the speaker implies "thus, it is too early to have Christmas products in the shops." Moreover, many opinions and evidence were expressed implicitly, stretched over a number of turns or even allowed to drift off. This is not only a strategy for avoiding a face threat, but also the difficulty of translating feelings and beliefs (which opinions are meant to express) into words. The emotional investment in opinions may explain the presence of unfinished opinions, leaving the interlocutor to do the work of interpreting what the speaker meant.

As suggested earlier, the Polish style of expressing opinions may appear confrontational when compared to the Irish participants' strategies. The data analysis of the role-play revealed, for instance, that some of the Poles in my study positioned themselves as outsiders and demanded an explanation, rather than enquiring about an opinion from the Irish interlocutor (regarding the Christmas rush). Moreover, the preferred Irish strategy was to pose an open question about an opinion, "What do you think about $x$ ?" while Poles phrased the question with their opinion implied in the introduction, for instance "Don't you think $x$ ?"

\section{Example 1. Scenario: Talking about getting a driving licence - Polish data.}

$<$ Magda $>\mathrm{Hi}$. I was thinking of getting driving licence. What do you think? $<$ Friend1 starts shaking head\} $>$ Don't you think it's like very useful nowadays? No?

The "Don't you think $x$ ?" formulation puts more pressure on the interlocutor to agree and makes disagreement more difficult, thus requiring more complex facework (and perhaps also syntax). A disagreement to "Don't you think $x$ ?" nearly pleads for a hedged response such as "Well, actually, I

\footnotetext{
The use of question tag 'No?' may be a pragmatic transfer from the Polish tag 'Nie?/ Co nie?'.
} 
don't think $x$." This is because rhetorical questions in exchanges of opinions are arguably one of the strongest stance markers on behalf of the speaker. They are 'the truth', which is not expected to be 'negotiated' - and this is believed to be the ultimate weapon in arguments (Danielewiczowa 1991, 161). Without some softening devices, the disagreement could be compared to a counter-attack to the original 'opinion as a question' by firing back at the speaker. The less frequent use of this strategy in the Irish data suggests that it is not a preferred way of expressing opinions in IrE. Moreover, Polish opinions are believed to be expressed more dogmatically, without a strong emphasis on the subjectivity of the claims of the speaker or concern for the hearer. The use of "Don't you think $x$ ?" is an example of this preference among the Polish participants. The speaker's position is quite strong in uttering those words, suggesting they are right and that the hearer should see that he or she is wrong. This contrasts with the Irish preference for using introductory moves and indirectly enquiring about someone else's opinion. Additionally, further dialogues in the Irish data were often garnished with abundant hedging, hesitation, indirectness and concessive (dis)agreements.

Example 2. Scenario: Talking about getting a driver's licence - Irish data.

$<$ Andy> Hi there. I went to see about getting my driver's licence, there, the other day. $<$ Friend1 $>$ Why?

$<$ Andy $>$ You kinda- you kinda need one, like, you know.

$<$ Friend1 $>$ Yeah... I have no interest=

$<$ Andy $>=$ yeah $=$

$<$ Friend1 $>=$ it's too expensive.

$<$ Andy ' 'tis alright $=$

$<$ Friend1 $>=$ you have to get the lessons, like.

$<$ Andy> 'Tis alright, but like, I suppose in the long run, you know, it'd be kinda great, probably gonna save me money. [...]

The different face needs that are behind Irish/Polish preferences can potentially lead to the misinterpretation of each other's intentions in exchanges of opinions. Poles may think Irish 'beat around the bush' while the Irish may find Poles confrontational and direct. However, the risk of a serious breakdown in communication is not a threat to be concluded from the role-play data.

\subsection{Focus Group Results}

Dealing with disagreements was one of the most discussed issues in relation to exchanges of opinions in the focus groups. In terms of differences between themes raised while talking about reactions to disagreement the Irish groups mentioned emotional involvement in the topic, while the Polish groups focused on knowledge instead. The Irish participants mentioned, for instance, the importance of beliefs and folklore in shaping one's opinions (as opposed to facts). On the other hand, among Polish participants, reactions to disagreement were discussed in relation to determining the believability of the arguments presented by the interlocutor. The key words in the Polish groups were argumenty (points), zargumentować (to reason) and wiedza (knowledge). Another theme common to both groups was the focus on the interlocutor and putting oneself in their position. However, in the Irish groups, again, it had a stronger emotional dimension, stressing a conciliatory approach to the interaction. The relationship between the interlocutors was stressed as more important than being right or wrong. In the Polish group, on the other hand, putting oneself in the interlocutors' place had the aim of understanding their opinion to prepare a better counter-attack rather than empathising with them. 
The most obvious difference emerging from the above summary is between understanding one's emotions and understanding one's opinion by analysing their arguments, which can be traced to previous studies of cultures according to uncertainty avoidance (Hofstede 1980, 1984). Thus, to Poles, who have a lower acceptance for uncertainty, facts are of a high importance in an exchange of opinions. The Irish culture, on the other hand, accepts uncertainty and how one came to form a certain view appears to be less important than the opinion itself. Furthermore, the emotional value of the opinion is what validates it, not the facts. As one Irish participant (in the role of Boss) said, "[It's not like you can] just develop a fact box and be able to bring it out every time [...] You have to take every person's true position into account."

The two main themes that emerged in both the Irish and Polish groups as a typically Irish way of expressing opinions were the use of strategic approach and, in a sense, being 'politically correct', which allows speakers to be ambiguous in expressing their point of view. This means that a person can assess the situation (especially if they are not the first person to offer the opinion) and 'go either way'. This strategic approach is also seen in 'active listening' and acknowledging the other person's input with the use of formulaic expressions such as 'I see what you mean' - a strategy acknowledged and commended in one of the Polish focus groups:

\section{Excerpt 1. Acknowledging interlocutor's point commended by a Polish participant.}

$<$ Jurek> Ale Irlandczycy... no ale oni tak fajnie bo coś im powiesz i oni na przyktad się z toba nie zgadzaja to... Oh I see where you're coming from, BUT! I wprowadzają swój argument. I później ja mówię no zgadzam się z tym punktem ale nie z tym i tak... no nie zgodzimy się, no mówi się trudno. Może zgodzimy się następnym razem. Nie sądzę żeby to byto coś wielkiego.

(But the Irish... it's nice because if you tell them something and they for example do not agree with you then... 'Oh I see where you're coming from, BUT!' and they introduce their argument. And then I say that I agree with this point, but not with that one and so... well, we won't agree, then tough. Maybe we'll agree next time. I don't think it's a big deal.)

The Irish groups also mentioned explicitly that in Ireland people expect hedging and indirectness to maintain the ambiguity and neutrality of opinions. Some participants assigned this attitude to the idea of a colonial master where "you do your work for them and it's yes sir, yes sir, and then talking behind their back... what a..."5 Others mentioned political correctness where there is a "strong move towards being completely above board on everything." This results in people being almost afraid of expressing their opinions. One expression that fulfils this function is saying, "I don't know," which signals to our interlocutor that we do not wish to explore the topic further, meaning, "I'm not trying to say that I know the answer, but I'm trying to plant the seed that you mightn't know either." As one participant observed, "the amount of times yes and no would be put in the same sentence to correlate the same point by an Irish person would be massive."

The reluctance to express real opinions is also reflected in $\mathrm{IrE}$ in examples such as in the use of the verb 'to doubt', which, due to semantic shift, actually means to 'strongly believe' in IrE (Todd 1989, 34-35, 40). These types of semantic discrepancies between varieties of English can be a source of trouble for those who are unaware of them. However, the example of the verb 'to doubt' may also be just the tip of the iceberg when one considers the Irish fondness of indirectness. In fact, a short quote from one of the Irish focus groups summarises quite well the opaque and 'twisted' ways of speaking in Ireland:

See Martin (2005) on indirectness and lack of self-revelation as the "legacy of colonialism" in Ireland. 
Excerpt 2. Speaking indirectly in Ireland.

$<$ Stranger2 $>[\ldots]$ People never say what they're actually thinking.

$<$ Boss $2>$ Or they say what they're NOT thinking=

$<$ Stranger2 $>=$ Yes, and see what you're gonna think about it.

Overall, the results of both role-play and focus group data provided additional evidence for the already documented characteristics of Polish 'dogmatic opinions' and Irish preference for indirectness.

\subsection{Discussion}

Since the current study investigated exchanges of opinions, one of the most relevant scripts available in reference to English are those explaining the differences between the expressions 'I think' and 'I know' (in Australian English, AuE henceforth), as presented below.

'I think' vs. 'I know'

when I want to say something about something

it is good to think like this:

if I don't know something I can't say that I know it

if I think something about something,

I can say that I think like this, I can't say that I know it

(Goddard 2003, 131, quoted in Mullan 2010, 70)

This means that in Australian culture (and probably within the Anglo cluster), the difference between a fact and an opinion is quite clear. An opinion is subjective, and one should thus not express it as something certain, something they 'know' but rather more subjectively, that they 'think' or 'it seems to them that $x$ '.

A study of the expression 'I think' in AuE further suggested a cultural script in relation to Australian culture and expressing opinions, which entails a whole set or 'rules':

it is not good for people always to say what they think

because of this, I do not always say what I think

there are things that I do not want to say

when I say what I think about something

I cannot say it like a thing that I know

I cannot say it like a thing that is true

if I do, people will think something bad about me

when I say what I think about something

it is good to say something like this:

'I think this

I know that other people don't have to think the same'

(Mullan 2010, 263) 
Therefore, the script above explains how one should behave and what one can expect in Australian society with reference to exchanging opinions. For instance, "it is not good for people to always say what they think" expressed as advice could help a person to whom Australian culture is alien. Moreover, expressing an opinion as a fact can lead to someone being perceived as impolite; that is, "people will think something bad about me." The final part of the script also offers advice as to respecting others' opinions by simply stating that "other people don't have to think the same."

The use of cultural scripts allows making a connection between a language and its culture. Here, the expression 'I think' can be linked to existing values in Australian culture. The question is whether principles such as "it is not good for people to say what they think" can be applied to all English-speaking cultures, and, most importantly, to the Irish culture. Evidence from the focus groups points to these principles, suggesting that, indeed, the principles also apply to the Irish context. These are presented in table 1.

TABLE 1. Cultural scripts for opinions with Irish focus group data examples.

\begin{tabular}{|c|c|c|}
\hline \begin{tabular}{|l|} 
Cultural \\
Script \\
Principle
\end{tabular} & $\begin{array}{l}\text { Australian English Cultural } \\
\text { Script (Mullan 2010, 263) }\end{array}$ & Irish Focus Group Example \\
\hline 1 & $\begin{array}{l}\text { it is not good for people always } \\
\text { to say what they think }\end{array}$ & $\begin{array}{l}<\text { Dave }>\text { But... ehm... to give an opinion at the party } \\
\text { about other individuals you should- you'd probably } \\
\text { choose to keep it to yourself. }\end{array}$ \\
\hline 2 & $\begin{array}{l}\text { because of this, I do not always } \\
\text { say what I think }\end{array}$ & $\begin{array}{l}<\text { Stranger1 }>\text { Yeah, but like when we first went into } \\
\text { that situation, I knew immediately that I was going } \\
\text { to start hedging... Like, I wouldn't walk right up to a } \\
\text { stranger and I wouldn't expect them to walk right up } \\
\text { to me and be like 'God! This is crap', you know that } \\
\text { kind of a way. [...] }\end{array}$ \\
\hline 3 & $\begin{array}{l}\text { there are things that I do not } \\
\text { want to say }\end{array}$ & $\begin{array}{l}<\mathrm{R}>\text { So what sort of opinions is it better to keep to } \\
\text { yourself? } \\
<\text { Peter }>\text { With the party you couldn't really say why } \\
\text { the fuck did she pick this place... } \\
<\mathrm{R}>\mathrm{Mhm} . . \\
<\text { Peter }>\text { Like, you could I suppose, but you'd appear } \\
\text { extremely rude... especially to a stranger. }\end{array}$ \\
\hline 4 & $\begin{array}{l}\text { when I say what I think about } \\
\text { something } \\
\text { I cannot say it like a thing that } \\
\text { I know } \\
\text { if I do, people will think } \\
\text { something bad about me }\end{array}$ & $\begin{array}{l}<\mathrm{R}>\text { So what opinions do you think it's better to } \\
\text { keep to yourself? } \\
{[\ldots]} \\
<\text { Boss3> Things that you don't know anything } \\
\text { ABOUT. I know it didn't come up but I wouldn't } \\
\text { start talking about anything I didn't know anything } \\
\text { about 'cos then I'd seem like a fool. }\end{array}$ \\
\hline
\end{tabular}




\begin{tabular}{|c|c|c|}
\hline 5 & $\begin{array}{l}\text { when I say what I think about } \\
\text { something } \\
\text { I cannot say it like a thing that } \\
\text { is true } \\
\text { if I do, people will think } \\
\text { something bad about me }\end{array}$ & $\begin{array}{l}<\text { Friend } 1>\text { I think if someone is always my way, my } \\
\text { way, my way then you (would) just kind of make it a } \\
\text { running joke about them, you know. }\end{array}$ \\
\hline 6 & $\begin{array}{l}\text { when I say what I think about } \\
\text { something } \\
\text { it is good to say something like } \\
\text { this: } \\
\text { 'I think this } \\
\text { I know that other people don't } \\
\text { have to think the same' }\end{array}$ & $\begin{array}{l}<\text { Stranger } 2>[\ldots] \text { I mean if somebody has a genuine } \\
\text { difference of opinion ehm... fair enough. You know, } \\
\text { we try and ehm... empathise where they're coming } \\
\text { from sometimes but, you know, it DEPENDS again } \\
\text { on the- on the issue. [...] } \\
<\text { Stranger } 2>\text { And there's a point when in some } \\
\text { arguments everyone is actually right but they're } \\
\text { coming at it from a different angle. [...] }\end{array}$ \\
\hline
\end{tabular}

In contrast, the above scripts may not fully correspond to the Polish script for thinking, and thus expressing opinions. The cultural preference for saying 'exactly' what one thinks is reflected in the Polish script for expressing opinions. The fundamental difference between a fact and an opinion echoes once again in how expressing opinions is approached by native speakers of English. Because opinions and facts are so epistemologically different, it is not expected that opinions should be based on facts. However, this sort of understanding may not be so clear in Polish. In fact the importance of presenting good arguments and facts discussed by Polish participants in the focus groups leads to the conclusion that opinions are meant to be based on facts. One possible interpretation of such preference is the unique script for 'opinions based on facts' with reference to Polish culture I propose below.

When I say I think something

I say it because I know something that is true and that I know

OR

When a person says they think something

they say it because they know something that is true and that they know

Following this scheme, Poles approach an exchange of opinions from the principle that when "a person says they think something," that is, when they express an opinion, it is because they base their opinion on a fact. Thus, the basis on which an opinion and a fact is constructed appears to be quite similar - reality, an event, a phenomenon that can be proven to have happened or to exist. This is in direct contrast with the English script for a categorical difference between a fact and an opinion, which are linear opposites of each other on a subjectivity continuum. In Polish culture, on the other hand, one seems to be the result of the other (opinion is a result of facts). The focus group data suggest that there is a link between opinion and fact that has a causative dimension, or even a reversed causative dimension. That is, to Poles, opinions are somehow expected to be based on facts, thus supported by evidence in exchanges of opinions. In the English-speaking world, the basis for an opinion is a belief, whereas "facts are facts" and can be verified on grounds that opinions cannot (Wierzbicka 2006, 41-46). Furthermore, the process of placing an utterance 
along a subjectivity continuum is a result of a shared mutual belief or a negotiation of meaning. Speakers who come from different cultures and languages may not share the same belief about what constitutes an opinion or a fact. Moreover, they may assign different value to opinions and facts, which is an issue emerging in the discussion with reference to Irish and Polish cultures.

While some semantic scripts about opinions in Polish culture and language have been explored, they deal mostly with the issue of expressing opinions honestly, for instance:

Polish - it is good to say what I think

Anglo - it is not always good to say to another person what I think

about this person

if I say it this person can feel something bad because of it

(Wierzbicka 1999, 272)

Furthermore, in Polish honest opinions are expressed despite the fact that the addressee may not like what they hear, as the elaborated script suggests:

(1) I want people to know what I think

If I think that someone thinks something bad,

I want to say it to this person

(2) if someone says something to me

I want to say to this person what I think about it

if I think something bad about it,

I want to say it to this person

(3) If I think that you think something bad

I want to say it to you

I don't want you to think something bad

(Wierzbicka 1994, 81)

Focusing on the last three lines of the script proposed by Wierzbicka, the need to 'correct' others ("I don't want you to think something bad," meaning 'wrong') is what stands out as different to the Anglo script. This characteristic sums up the Polish attitude towards perlocution and convincing the interlocutor, or correcting their point of view. The most common way to change someone's mind is to provide evidence which, in turn, will change their belief about something. This could explain the focus on presenting good arguments and trying to convince the interlocutor which emerged in the Polish focus groups.

Along the lines of the differences between 'knowing' and 'thinking' or 'reason' and 'emotion', another disparity between Polish and Irish attitudes became apparent, namely, compromising. Compromising is believed to be tied to a negative emotion in Polish, signalling a weakness of character, giving up and essentially losing an argument. However, it is said that in English it has more positive connotations, being seen as a result of negotiation, an objective to be reached when one's opinions differ (Wierzbicka 1985; 2003, 48-49). What the focus groups also revealed about compromising is a more rational approach to exchanges of opinions among Poles, who often talk about presenting arguments in a discussion. Consequently, when Poles fail to convince their interlocutor with the arguments presented and, subsequently, they are forced to compromise, it 
feels like they have failed and thus compromise reluctantly. Standing one's ground is important and compromising is a result of the other person not convincing the interlocutor to their viewpoint, as expressed by one of the Polish participants: “... no dobrze to jest twój punkt myślenia, to jest mój $i$ zostajemy przy swoim, no nie przekonteś mnie i tyle" (“... okay, that's your point of view, this is mine and we agree to differ, you just didn't convince [author's emphasis] me and that's it").

In comparison, the Irish focus groups talked about taking the interlocutor's true position into account to empathise with them and try to understand them, stressing the emotional side of expressing opinions.

\section{Excerpt 3. Empathise with your enemy.}

$<$ Stranger2 $>[\ldots]$ empathise with your enemy. So see where they're coming from and, okay, don't agree with them, you know that there'll be no middle ground but try and get inside where they're coming from and realise that they have a certain- even if the guy knows himself that he's not right and that he's not gonna back down out of in a sense of losing face or feeling weaker so just, you know...

Therefore, when the Irish fail to understand a person, it is less of a lost battle because they tried their best to understand that person and not to make that person see their point. This attitude points to a sort of a paradox when it comes to cultural values, considering previous research on Polish and Irish cultures. On the one hand, there is the Irish (and Anglo-cluster) reluctance to expressing strong emotions, which is reflected in the fact that in Ireland people 'do not say what they really mean', but they try to emotionally empathise with their interlocutor. Feeling and believing is what makes an opinion valid. On the other hand, Polish culture allows for exposure of strong feelings, even if they are negative feelings, such as reprimanding someone in public spheres (Hoffman 1989, 438; Wierzbicka 1985, 16). However, it also pushes emotions to second plan in exchanging opinions, giving more value to rational evidence which validates opinions in Polish discussions. This latter rational attitude discovered in my data is an aspect which may be added to the previously described cultural scripts for opinions in Polish, as I propose earlier. The Irish script seems to reflect rather closely the script described with regards to the Australian variety of English on the general level. The uniqueness of IrE opinions may be then visible in the execution of such scripts in communication manifested in particular pragmatic strategies such as IrE discourse markers or hedges.

\section{Conclusion}

In my paper I have argued that opinions described in terms of cultural scripts for expressions 'I think' and 'I know' in IrE show characteristics similar to those described with reference to $\mathrm{AuE}$. That is, there is a clear difference between opinions and facts which must be signalled in communication, and the inherent respect for opinions of others and one's own honour by not expressing subjective statements as facts. In contrast, in Polish opinions, the principle of frankness may override other politeness maxims (such as indirectness), and Polish speakers of English may transfer these strategies into English. Furthermore, the distinction between fact and opinion in Polish culture may not reflect the Anglo rules; rather, the results suggest that in Polish opinions may need to be supported by facts to be valid.

The consequences of these differences may result in misinterpreted intentions of speakers in PolishIrish English-medium exchanges of opinions. On the one hand, the Irish side in such dialogues may 
find the Polish style too direct and confrontational or even dry because of the stress on presenting facts. On the other hand, Poles may find Irish interlocutors rather vague and uncommitted to their opinions. While a breakdown in communication is not a conclusion to be drawn from the results, a certain level of possible emotional miscommunication should be noted. On a positive note, the indication of the existence of the differences in attitudes, provided by this research, should also be seen as the first step in the process of the two cultures understanding each other better.

Regarding the limitations of the current study, firstly, it should be acknowledged that using a larger number or participants would have allowed me to make stronger generalisations. However, in compromising scale for focus, research gains integrity and data of similar size to the corpus gathered in the current study have been reported in the field of discourse analysis in Ireland (Palma Fahey 2005; Vaughan 2009). In addition, it is important to note that gathering a corresponding corpus of Polish-Polish interactions would have added further value to the contrastive aspect of comparing speech act behaviour between different cultures. Therefore, it is recommended that future studies should aim to triangulate data to address both cross-cultural as well as intercultural paradigms in similar research.

The conclusions and boundaries of this study open a number of avenues for future research. In the first place, it is important to mention the value of using spoken data in researching politeness. Role-plays provided rich material for analysis in the present study. However, while the interactions recorded in the role-plays allowed for a balanced comparison between the two linguistic groups, future studies should aim to use naturally occurring data and strive for a larger sample. Collecting naturally occurring samples would also provide richer data for corpus analysis, especially in contrasting Irish strategies with large, international corpora.

Another suggestion for future research refers to the application of alternative analytical frameworks. The fields of Interactional Sociolinguistics or Conversational Analysis could provide an opportunity to analyse opinions from a structural-sequential perspective. Furthermore, the NSM and concept of cultural scripts could enrich the study of opinions by providing an unbiased, intercultural clarity in describing and analysing opinions across languages and cultures. Further explications of the speech act set, and perhaps extending description to a variety of contexts and modes, could provide an extensive classification of opinions.

As a concluding remark, it may be important to note that research in cross-cultural pragmatics has been limited to a few speech acts, and clearly there is a need for new speech acts to be investigated. The study described here has been intended as a small step in addressing this apparent gap in our knowledge of intercultural communication with the hope of opening an avenue for further research into opinions and cultural scripts.

\section{References}

Aitchison, Jean. 1999. "Review of Anna Wierzbicka’s Understaning Cultures through Their Key Words: English, Russian, Polish, German and Japanese. Oxford: Oxford University Press. 1997.” International Journal of Lexicography 12 (1): 87-89. doi:10.1093/ijl/12.1.87.

Blum-Kulka, Shoshana, Juliane House, and Gabriele Kasper. 1989. Cross-Cultural Pragmatics: Requests and Apologies. Norwood: Ablex.

Braun, Virginia, and Victoria Clarke. 2006. "Using Thematic Analysis in Psychology." Qualitative Research in Psychology 3 (2): 77-101. doi:10.1191/1478088706qp063oa. 
Brown, Penelope, and Stephen Levinson. 1987. Politeness: Some Universals in Language Usage. Cambridge: Cambridge University Press.

Central Statistics Office. 2012. Census 2011: Profile 6 - Migration and Diversity. Dublin. Accessed March 30, 2015. http://www.cso.ie/en/census/census2011 reports/census2011 profile6migrationanddiversityaprofileofdiversityinireland.

Culpeper, Jonathan. 2011. Impoliteness: Using Language to Cause Offence. Cambridge: Cambridge University Press.

Danielewiczowa, Magdalena. 1991. "Zdania pytajne o funkcji ekspresywnej.” Jezzy a Kultura 4:159-68.

Doughty, Steve. 2012. "Why a Pole’s Politeness Can Be Lost in Translation." Daily Mail, February 14. Accessed March 30, 2015. http://www.dailymail.co.uk/news/article-2100727/Why-Poles-politeness-lost-translation. html.

Eggins, Suzanne, and Diane Slade. 1997. Analysing Casual Conversation. London: Cassell.

Farr, Fiona, Bróna Murphy, and Anne O’Keeffe. 2004. “The Limerick Corpus of Irish English: Design, Description and Application.” Teanga 21:5-30.

Gąsior, Weronika Zofia. 2014. "Intercultural Pragmatics: An Investigation of Expressing Opinions in Irish English amongst Irish and Polish Students.” PhD Diss., University of Limerick.

Goddard, Cliff. 2002. "Explicating Emotions across Languages and Cultures: A Semantic Approach.” In The Verbal Communication of Emotions: Interdisciplinary Perspectives, edited by Susan R. Fussel, 19-54. Mahwah: Lawrence Earlbaum.

—. 2008. "Natural Semantic Metalanguage: The State of the Art." In Cross-Linguistic Semantics, edited by Cliff Goddard, 1-34. Amsterdam: John Benjamins.

Goddard, Cliff, and Anna Wierzbicka. 2004. "Cultural Scripts: What Are They and What Are They Good for?" Intercultural Pragmatics 1 (2): 153-66.

Guest, Greg, Kathleen M. MacQueen, and Emily E. Namey. 2012. Applied Thematic Analysis. London: Sage.

Hoffman, Eva. 1989. Lost in Translation: A Life in a New Language. New York: Penguin.

Hofstede, Geert. 1980. Culture’s Consequences: International Consequences in Work-Related Values. Beverly Hills: Sage.

—. 1984. Culture's Consequences: International Differences in Work-Related Values. London: Sage.

Jefferson, Gail. 2004. “Glossary of Transcript Symbols with an Introduction.” In Conversation Analysis: Studies from First Generation, edited by Gene H. Lerner, 13-23. Amsterdam: John Benjamins.

Kalisz, Roman. 1993. “Different Cultures, Different Languages, Different Speech Acts Revisited.” Papers and Studies in Contrastive Linguistics 27:107-18.

Kallen, Jeffrey L. 2005. "Silence and Mitigation in Irish English Discourse." In The Pragmatics of Irish English, edited by Anne Barron and Klaus P. Schneider, 47-71. Berlin: Mouton de Gruyter.

Klos Sokol, Laura. 1997. Shortcuts to Poland. Warsaw: Wydawnictwo IPS.

Mullan, Kerry. 2010. Expressing Opinions in French and Australian English Discourse. Amsterdam: John Benjamins.

Murray, D. W., and Gregory Button. 1988. "Human Emotions: Some Problems of Wierzbicka's 'Simples'." American Anthropologist 90 (3): 684-86. doi:10.1525/aa.1988.90.3.02a00130.

O’Keefe, Anne, Brian Clancy, and Svenja Adolphs. 2011. Introducing Pragmatics in Use. Abingdon: Routledge.

Palma Fahey, María. 2005. "A Cross-cultural Discourse and Pragmatic Analysis of Two Soap Operas: Fair City and Amores de Mercado Compared." PhD Diss., Mary Immaculate College, University of Limerick.

Patton, Michael Quinn. 2002. Qualitative Research and Evaluation Methods, 3rd ed. London: Sage. 
Rakowicz, Agnieszka. 2009. Ambiguous Invitations: The Interlanguage Pragmatics of Polish English Language Learners. Saabrücken: VDM (Verlag Dr. Müller).

Ramson, William S. 2001. "Anna Wierzbicka and the Trivialization of Australian Culture." Australian Journal of Linguistics 21 (2): 181-94. doi:10.1080/07268600120080550.

Schiffrin, Deborah, Deborah Tannen, and Heidi E. Hamilton. 2001. The Handbook of Discourse Analysis. Oxford: Blackwell.

Scott, Mike. 2006. WordSmith Tools, Liverpool: Lexical Analysis Software.

Stewart, Edward C, and Milton J. Bennett. 1991. American Cultural Patterns. Yarmouth: Intercultural Press.

Super, Paul. 1939. The Polish Tradition: An Interpretation of a Nation. London: George Allen \& Unwin Ltd.

Todd, Loreto. 1999. Green English: Ireland's Influence on the English Language. Dublin: O’Brien Press.

Vaughan, Elaine. 2009. “Just Say Something and We Can All Argue Then': Community and Identity in the Workplace Talk of English Language Teachers.” PhD Diss., Mary Immaculate College, University of Limerick.

VOICE Project. 2007. "VOICE Transcription Conventions [2.1].” Accessed March 22, 2013. http://www. univie.ac.at/voice/voice.php?page=transcription general information.

Wierzbicka, Anna. 1985. "Different Cultures, Different Languages, Different Speech Acts: Polish vs. English.” Journal of Pragmatics 9 (2-3): 145-78. doi:10.1016/0378-2166(85)90023-2.

—. 1994. “'Cultural Scripts': A New Approach to the Study of Cross-Cultural Communication.” In Language Contact and Language Conflict, edited by Martin Pütz, 69-87. Amsterdam: John Benjamins.

- 1996. Semantics: Primes and Universals. Oxford: Oxford University Press.

—. 1997. Understanding Cultures through Their Key Words: English, Russian, Polish, German and Japanese. New York: Oxford University Press.

-. 1999. Emotions across Languages and Cultures: Diversity and Universals. Cambridge: Cambridge University Press.

- 2003. Cross-Cultural Pragmatics: The Semantics of Human Interaction. 2nd ed. Berlin: Mouton de Gruyter.

—. 2006. English: Meaning and Culture. New York: Oxford University Press.

"World Proverbs: Proverbs with Opinion.” 2005-2013. In Special Dictionary. Accessed: March 22, 2015. http:// www.special-dictionary.com/proverbs/keywords/opinion/2.htm.

Zinken, Jörg, and Eva Ogiermann. 2013. "Responsibility and Action: Invariants and Diversity in Requests for Objects in British English and Polish Interaction." Research on Language and Social Interaction 46 (3), 25676. doi:10.1080/08351813.2013.810409. 